\title{
Hasta Hakları Uygulamalarının Hasta Memnuniyeti Üzerindeki Etkisinin İncelenmesi*
}

\author{
Yasemin Karaca $^{1 \dagger}$, Menekşe K1lıçarslan ${ }^{2}$ \\ Yüksek lisans tezinden üretilmiştir. \\ 1*i̇stanbul Aydın Üniversitesi, Sağlı Bilimleri Fakültesi, Sağlık Kurumları Yöneticiliği Bölümü, İstanbul, Türkiye,(ORCID: 0000-0003-3529-1154), \\ ysmnkrcc@outlook.com.tr \\ ${ }^{2}$ İstanbul Aydın Üniversitesi, Sağlık BilimleriFakültesi, Sağlık Yönetimi Bölümü, İstanbul, Türkiye (ORCID:0000-0002-0580-8645), meneksekilicarslan@aydin.edu.tr
}

(İlk Geliş Tarihi Aralık 2020 ve Kabul Tarihi Ocak 2021)

(DOI:10.31590/ejosat.852196)

ATIF/REFERENCE: Karaca, Y. \& Kılıçarslan, M. (2021). Hasta Haklarının Hasta Memnuniyeti Üzerindeki Etkisinin İncelenmesi. Avrupa Bilim ve Teknoloji Dergisi, (22), 430-435.

$\ddot{O} \mathbf{z}$

Çalışma, hastane işletmelerinde tedavi gören hasta ve hasta yakınlarının görüşlerine göre hasta hakları uygulamalarının hasta memnuniyeti üzerindeki etkisinin incelenmesi, sağlık hizmetlerine göre görüşlerini belirlemek ve ilgili sorulara göre çözüm önerileri geliştirmek amacıyla yapıldı. Araştırma, devlet hastanesinde yatarak tedavi gören ve poliklinik hastaları ve hasta yakınları ile gerçekleştirildi. $\mathrm{Bu}$ amaç doğrultusunda 300 hasta ve yakınına hasta hakları uygulamaları ölçeği ve hasta memnuniyeti ölçeği uygulanmıştır. Verilerin toplanmasında demografik özellikler, alınan tedavi hizmeti ve bunun memnuniyete yansımasına yönelik görüşleri içeren ölçek formu kullanıldı. Hasta hakları uygulamaları ölçeği 7 maddeden oluşan tek boyutlu bir ölçektir. Hasta memnuniyeti ölçeği 13 maddeden oluşan 3 boyutlu bir ölçektir. Çalışmada elde edilen veriler SPSS 18 (Statistical PackagefortheSocialSciennes) ve AMOS 22 paket programı kullanılarak analiz edilmiştir. Hasta hakları ve hasta memnuniyeti ölçeklerinin her ikisinde de güvenirlik analizi için Cronbach's Alpha katsayısı hesaplanmış, yapısal geçerliliği için doğrulayıcı faktör analizi (DFA) uygulanmıştır. Hasta hakları uygulaması algısı düşük düzeyde bulunmuştur. Hasta memnuniyeti algısı orta düzeyin biraz üzerindedir. Hasta hakları ve hasta memnuniyeti algılarında demografik değişkenler bakımından çoğul durumda farklılık bulunamamıştır. Hasta hakları uygulamaları algısının hasta memnuniyeti üzerindeki etkisi istatistiksel olarak anlamlı bulunmuştur. Ancak hasta hakları uygulamaları algısının idari hizmet ya da memnuniyet üzerinde istatiksel olarak anlamlı bir etkisi olmadığı görülmüştür.

Anahtar Kelimeler: Hak, Hasta, Hasta Hakları, Hasta Memnuniyeti, Memnuniyet.

\section{Investigation of the Effect of Patient Rights Practices on Patient Satisfaction}

\begin{abstract}
The study was carried out to examine the effect of patient rights practices on patient satisfaction according to the opinions of patients and patient relatives who were treated in hospital enterprises, to determine their opinions according to health services and to develop solutions according to the related questions. The research was carried out with outpatients, inpatients and their relatives in the public hospital. For this purpose, patients' rights scale and patient satisfaction scale were applied to 300 patients and their relatives. In the data collection, a survey including demographic specifications, treatment service received and opinions about its reflection on patient satisfaction was used. Patient rights practices scale is a one-dimensional scale consisting of 7 titles. Patient satisfaction scale is a 3 dimensional scale consisting of 13 titles.The data obtained in the study were analyzed using SPSS 18 (Statistical Package for the Social Sciences) and AMOS 22 package program.Cronbach's Alpha coefficient was calculated for reliability analysis in both patient rights and patient satisfaction scales and confirmatory factor analysis (CFA) was applied for structural validity. Patient rights practice perception was found to be low. Patient satisfaction perception is slightly above the average. There was no difference in the plural situation in terms of demographic variables in patient rights and patient satisfaction perceptions. The effect of patient rights practice perception on patient satisfaction was found statistically significative. However, it has been observed that the perception of patient rights practices does not have a statistically significant effect on administrative service or satisfaction.
\end{abstract}

Keywords: Rights, Patient, PatientRights, PatientSatisfaction, Satisfaction

\footnotetext{
${ }^{*}$ Bu çalışma sorumlu yazarın yüksek lisans tezinden türetilmiştir.

†Sorumlu Yazar: İstanbul Aydın Üniversitesi, Sağlık Bilimleri Fakültesi, Sağlık Kurumları Yöneticiliği Bölümü, Beşyol/İstanbul,Türkiye, ORCID: 0000-0003-3529-1154, ysmnkrcc@ outlook.com.tr
} 


\section{Giriş}

Günümüzde bilginin öneminin artması ile bilgi çağına hızlı bir geçiş olduğu gibi bu geçiş her alanda farklılıklar ve değişimler yaratmıştır. Bireylerin yaşam kalitelerinin yükseltilerek, sağlık hizmetlerindeki ihtiyaçları doğrultusunda planlamalar yapilarak, hizmetlerin sunulması ve değerlendirilmesinde toplumun her kesiminden bireyin ihtiyaçlarına cevap verecek nitelikte olmasına dikkat edilmelidir. $\mathrm{Bu}$ sebeple, sağlık hizmetlerinde ilerleyen süreçlerde teknolojik gelişmelerinde desteği ile yeni cihazlar ve tedavi yöntemleri geliştirilmektedir. $\mathrm{Bu}$ gelişmeler ve uygulamalar ile verilen hizmetin kalitesini arttırmak amaçlanmıştır. Hasta hakları, insani değerlerin ve insan haklarının sağlık hizmetlerinde uygulanmasıdır. Hasta haklarında amaç; sağlık personelleri ile hasta arasındaki ilişkileri desteklemek, hastaların sağlık hizmetlerinden tam olarak faydalanabilmesini sağlamak, sağlık hizmetlerinde etkinliği arttırmak, hizmet alan ve hizmet veren kurumlar arasındaki iletişim ve işbirliğini arttırmak, hasta haklarına yönelik olarak başvuru merkezleri oluşturmak ve hastalara sağlık hizmetleri verilirken iç kontrolün sağlanmasıdır.

Hasta hakları, sağlık hizmetinden yararlanan bireyin sağlık kurumları ve personelleri karşısındaki haklarını bildiren bir ifadedir. Hasta haklarının tam olarak korunabilmesi için sağlık personellerine düşen vazifeler de bulunmaktadır. Sağlık personellerinin görevlerini yerine getirirken hasta haklarını gözeterek hareket etmeleri hastaların sağlık kurumuna olan memnuniyetini arttırmaktadır.

Hasta memnuniyeti, bireyin almış olduğu sağlık hizmetinden beklentilerine ne kadar karşılık bulduğu ile ilgilidir. Sağlık, hayatın insanlara vermiş olduğu en önemli değerlerden biridir. Bilgi çağında olduğumuz bu zamanda sağlı̆̆ın değerini daha iyi anlamış olarak ve sağlığımızı koruyarak, gelecek nesillerin daha sağlıklı olması için çabalayarak ulusal gelire katkıda bulunulmalıdır. Ülkeler, sağlık hizmetlerinde kaliteyi arttırarak gelişmişlik düzeylerini arttırabilirler. Bu kapsamda çalışmanın problem cümlesi, hasta hakları uygulamaları ile hasta memnuniyeti arasında bir ilişkinin olup olmadığı olarak belirlenmiştir.

\section{Hasta Hakları Kavram veTanımı}

Dünya Sağlık Örgütü (DSÖ), sağlık tanımını üç farklı ayrım ile yapmıştır. Bunlar biyolojik, psikolojik ve sosyal iyilik halleri şeklindedir. Sağlık hakkını bu üç durum üzerinde yorumlamak mümkündür.

Bireylerin sağlık haklarının korunabilmesi için onlara bazı sağlık hizmetlerinin verilmesi gereklidir. Fakat amaç her daim bireylerin sağlıklı hallerinin devam etmesi için gerekli tedbirlerin alınarak korunmasıdır. Toplumların gelişmişlik ve refah düzeylerini artırmak, bireylerin mutlu ve sağlıklı bir yaşam sürmelerini sağlamak için sağlık hizmetlerinin iyi olması gereklidir (Aksoy, 2001). Hasta hakları ile ilgili yönetmeliğin 4. Maddesinde yer alan hasta hakları, sağlık ihtiyacı olan ve talepte bulunan kişilerin T.C. Anayasası, kanunlar, milletlerarası antlaşmalar ve diğer mevzuatlarda bulunan ve her bireyin insan olarak doğması nedeniyle doğuştan sahibi olduğu haklar olarak ifade edilir (T.C. Sağlık Bakanlığı, 05.03.2019).

Hasta hakları, sadece hekim-hasta ilişkisini değil, aynı zamanda sağlık kurumlarındaki tüm sağlık personellerini de kapsamaktadır. Hasta haklarında dile getirilen hasta hakkı bireyin hem hekim ile hem de kurum ile olan ilişkisinden meydana gelmektedir. $\mathrm{Bu}$ değerlendirmeden yola çıkarak günümüzde sadece "hasta-hekim" ilişkisinden bahsedemeyiz. Daha ayrıntılı olarak incelendiğinde en sağlıklı hasta hakları değerlendirmesinin hasta-sağlık personeli arasındaki ilişkinin incelenmesi ile ortaya çıkacağı anlaşılmaktadır. Sağlık kurumlarında hasta-sağlık personeli arasındaki iletişim ve ilişkide sağlık kurumları ve çalışanların otoritesi ön plandadır. Çünkü bu ilişki de hasta zor durumda olan taraf olarak sağlık hizmetine ve çalışana ihtiyacı vardır. Sağlık personellerinin tıbbi bilgileri ile ihtiyacı olan sağlık hizmetini alan hastanın pozisyonu farklı bir yer alır ve eşitlik burada söz konusu olmaktan çıkar. Bunlarla birlikte sağlık hizmetlerinde gelişen teknoloji ile tanı ve tedavi aşamasındaki bürokratik işlemlerin uzaması, hastaların korunması ve desteklenmesi için hasta hakları kavramını daha da önemli kılar (Hatun, 1999).

Sağlık kurumlarında çalışan personellerin hasta haklarını daha iyi anlayıp, hastaya hizmeti ona göre verip, yeri geldiğinde hastaları savunabilmeleri için empati kurmaları gereklidir. Aslında tüm bireyler potansiyel olarak hem hasta hem de hasta yakınıdır. $\mathrm{Bu}$ nedenle hasta hakları sadece hasta bireyler için değil aynı zamanda hasta olabilecek ya da hasta yakını olabilecek herkes için ve sağlık personelleri için de geçerlidir. Hasta hakları adı altında gündeme getirilen özelliklere genel olarak bakıldığında bir sağlık çalışanının hasta veya hasta yakını olup sağlık kuruluşuna ya da hekime başvurduğunda karş1 taraftan beklemiş olduğu davranışlar bütünüdür (Özlü, 2007).

\section{Hasta Memnuniyeti Kavramı}

Hizmet veren personel yapmış olduğu çalışma sonucunda ortaya somut bir fayda çıkarıyorsa, bundan duyacağı gurur ve keyif, çalışanın en büyük memnuniyet hali olacaktır. Yapılan işte memnuniyet durumunu etkileyen şartlar; bireyin zekâsına uygun bir iş olması ve ilgi alanına girmesi; kişinin çalışırken vermiş olduğu çabaya yönelik olarak kişiye duyulan saygınlık; çalışanı bedensel olarak çok yormaması uygun çalışma ortamının yaratılması şeklinde ifade etmiştir (Eren, 2006).

Psikologlar ve yönetim bilimciler tarafindan memnuniyet hakkında çeşitli teoriler oluşturmuşlardır. Farklı önem seviyelerini memnuniyet kavramına bağladılar. Bunları dışsal ve içsel faktörler şeklinde ayırmışlardır. İçsel olan faktörler, bireyin kişisel özellikleri ile ilgili olan davranış gibi eylemler iken, dışsal olan faktörler ise çalışma ortamına bağlı olarak durumsal bir etkidir. Dışsal teoriler genel olarak ekonomistler tarafından ifade edilen farklı terminolojideki durumlardır, içsel teoriler ise çevresel olarak sosyal bilimlerin ilgilendiği bir ilişki alanıdır (Petrescu ve Simmons, 2008).

Bireylerin zaman içerisinde yaşamış oldukları deneyimler, geleceğe yönelik olarak bekledikleri, psikolojik durumları, yaşam kaliteleri ve içinde bulundukları toplumsal değerleri içeren bireylerin algılarına ve bakış açılarına göre değişen karmaşık bir anlamı olan memnuniyet; "bireyin, hizmeti almasından önceki beklentileri ile aldıktan sonra ortaya çıkan performans arasındaki farka yönelik tepkisi" şeklinde ifade edilir. $\mathrm{Bu}$ ifadeden yola çıkarak hasta memnuniyeti, bireylerin beklentileri ile ihtiyaçları doğrultusunda almış oldukları bakım ve tedavi gibi sağlı hizmetleri sonrasında algıladıkları değişismin anlatılması şeklinde açıklanmaktadır (Akkaya vd., 2012). Hasta memnuniyetinde belirleyici özellikler olarak hastanın beklediği hizmet ve aldığı hizmet arasındaki farkın 
hasta tarafından algılanma şekli, sağlık kuruluşunun yönetsel ve akademik özellikleri ile hastanın cinsiyeti, eğitim durumu, yaşı, sosyokültürel yapısı, hastalığının türü ve tedavi süreci gibi özelliklere göre farklılık gösterebilmektedir. Bu nedenle "hasta memnuniyeti = beklenti ve algılama" bu şekilde bir formülasyon ortaya çıkarılmıştır (Özer ve Çakı1, 2007: 141). Sağlık hizmeti veren işletmelerin pazar paylarını ve karlarını arttırmalarında ve buna yönelik olarak belirlemiş oldukları hedeflerine ulaşmalarında müşteri memnuniyetini ön planda tutmaları çok önemlidir. Bu doğrultuda memnuniyetin arttırılması için hizmet kalitesinin arttırılması, memnuniyet yaratan hizmetlerin devamlılığının sağlanması, memnuniyetsizlik durumu yaratan olumsuzluklara çözümler bulunması hasta memnuniyetini arttırmak ve daha kaliteli hizmet vermeyi hedefleyen sağlık kuruluşları için yapmaları gereken uygulamalar olarak sayılabilir (Kavuncubaşı, 2000).

\section{Şekil 1. Hasta Memnuniyeti}

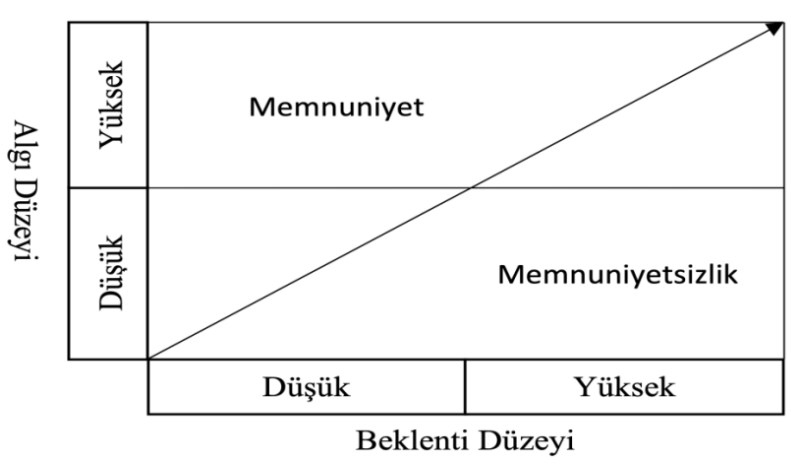

Kaynak: Fatma Nur Çiçin, "Kanserli Hastalara Sunulan Sağlık Hizmetlerinde Hasta Memnuniyeti ve Trakya Üniversitesi Balkan Onkoloji Hastanesi Örneği”, Trakya Üniversitesi, SBE, YLT, 2018, s.34.

Yukarıda yer alan şekilden de anlaşıldığı gibi hasta bireylerin beklentilerine karşıl1k verildiğinde memnuniyet seviyeleri artarken (algi>beklenti), beklentilerine karşılık alamayan hastalarda memnuniyetsizlik ( $\operatorname{algl}>$ beklenti), ortaya çıktığı gözlemlenmiştir (Çiçin 2018). İleriye yönelik hedefleri olan ve varlıklarını sınırsız olarak devam ettirmek isteyen sağlık kuruluşlarının müşteri (iç ve dış müşteri) memnuniyetini önemsemeleri ve ona göre hizmet vermeleri gereklidir. Bunu başarmak için de kuruluş yapı ve süreçlerini müşteri memnuniyetine, istek ve beklentilerine göre sürekli yenilemek, iyileştirmek, yeni stratejiler geliştirmek zorundadır.

\section{Uygulama}

\subsection{Araştırmanın Amacı}

Sağlık hizmetlerinin sunumunda performansın ve kalitenin temel göstergesi hasta ve yakınlarının memnuniyet düzeyleridir. Bu çalışmanın amacı, 2020 yılında X ilçesinde faaliyet gösteren kamu hastanesinde tedavi hizmeti alan hasta ve hasta yakınlarının hasta haklarına yönelik bilgi ve tutumlarının ölçülmesi ve memnuniyet düzeylerine etkisinin belirlenmesidir.

\subsection{Araştırmanın Önemi}

Hasta haklarına yönelik faaliyetlerin verimliliği ve etkinliği hem hasta memnuniyetini artırmakta hem de son zamanlarda artan hasta ve personel arasındaki şiddet gibi sorunların engellenmesinde fayda sağlayabilmektedir. $\mathrm{Bu}$ araştırma hem e-ISSN:2148-2683 hastaların memnuniyet durumunun hangi faktörlere bağlı olarak değiştiğini incelenmiş olacak hem de memnuniyete bağlı olarak hasta haklarına yönelik uygulamalar iyileştirilebilecektir.

\subsection{Araştırmanın Modeli}

Çalışma nicel araştırma modelindedir.Araştırmanın temel problemi olan hasta haklarının hasta memnuniyeti üzerindeki etkisi basit regresyon modeli ile incelenmiştir. Hasta memnuniyeti ölçeği 3 alt boyuttan oluştuğu için 4 ayrı basit doğrusal regresyon modeli uygulanmıştır. Modellerden birincisi genel memnuniyet için diğer üçü alt boyutları için oluşturulmuştur. Ölçeklerin yapısal geçerliliği için doğrulayıcı faktör analizi modeli oluşturulmuştur. Hasta hakları tek boyutlu ölçek olduğundan dolayı sadece 1.düzey DFA doğrulayııı faktör analizi oluşturulmuştur. Hasta memnuniyeti ölçeği alt boyutları olan bir ölçek olduğundan 1. Ve 2. Düzey DFA modelleri oluşturulmuştur. DFA modellerine ilişkin Amos programında oluşturulan model şemaları ekler kısmında verilmiştir. Nicel araştırma modeline uygun olarak istatistiksel analizler yapılmıştır.

\subsection{Araştırmanın Evren ve Örneklemi}

Araştırmanın hedef kitlesini kamu hastanesinde tedavi gören hasta ve yakınları oluşturmaktadır. Araştırmanın evreni bir kamu hastanesinde tedavi gören hasta ve yakınları olarak belirlenmiştir. Araştırma kapsamına yalnızca' Kamu Hastanesi olarak X ilçesindeki Devlet Hastanesi"seçilmiştir. Yaklaşık 100 bin üzerindeki nüfusa tedavi hizmeti vermektedir. Araştırmanın yapıldığı ilçede tek kamu hastanesi ve kamuya bağlı ağız ve diş sağlığ merkezi bulunmakta, 4 tane ise özel hastane yer almaktadır.Bu kapsamda ölçek soruları rastgele olarak seçilen hastaya araştırmacı tarafından dağıtılmış ve yine araştırmacı tarafindan toplanmıştır. Seçilen kamu hastanesinden toplanan ölçeklerden bir kısmı Genel cerrahi bir kısmı ise Kulak burun boğaz alanında tedavi gören hastalar ve yakınları ile yapılmış toplamda 300 ölçek formu elde edilmiştir.

\section{Yöntem}

\subsection{Veri Toplama Araçları}

Araştırmada anket veri toplama aracı olarak kullanılmıştır. Ölçek üç bölümden oluşmaktadır. Birinci bölümde katılımcıların demografik özelliklerini kapsayan kişisel tanıtıcı bilgi ölçeği, ikinci bölümde ise hastanedeki hasta hakları uygulamalarına müteveccih hasta ve yakınlarına uygulanan ölçektir. Üçüncü bölümde ise hastaların hizmetlerden memnuniyetlerini tespit etmeye yönelik hasta memnuniyeti ölçeği bulunmaktadır.

Hasta hakları ve hasta memnuniyeti ölçeklerinin her ikisi için de güvenirlik analizi için Cronbach's Alpha katsayısı hesaplanmış, yapısal geçerliliği için doğrulayıcı faktör analizi (DFA) uygulanmıştır. Ölçek soruları içinde hasta hakları algısını ölçmek amacıyla anket formunun Hasta Hakları bölümünde 11., 14., 15., 16., 17., 18., 19., 20. ve 21. sorular sorulmuştur. Hasta memnuniyeti algısı ise ayrı bir ölçek olarak 14 sorudan oluşan bir bölümde sorulmuştur.

\section{Bulgular}

$\mathrm{Bu}$ bölümde araştırma değişkenlerine ilişkin bulgular yer almaktadır. 
Tablo 1. Ankete katılan bireylerin demografik özelliklerine göre frekans dă̆ılımı

\begin{tabular}{ccc}
\hline Cinsiyet & Sayı & Yüzde \\
\hline Kadın & 136 & 45,3 \\
Erkek & 164 & 54,7 \\
\hline Yaş & & \\
\hline $\mathbf{1 8 - 2 4}$ yaş & 24 & 8,0 \\
25-30 yaş & 36 & 12,0 \\
31-35 yaş & 21 & 7,0 \\
36-40 yaş & 47 & 15,7 \\
41 yaş ve üstü & 172 & 57,3 \\
\hline Eğitim & & \\
\hline Lise & 231 & 77,0 \\
Ön Lisans & 41 & 13,7 \\
Lisans & 27 & 9,0 \\
Doktora & 1 &, 3 \\
\hline Medeni & & 81,3 \\
\hline Evli & 244 & 18,7 \\
Bekar & 56 & \\
\hline Gelir & & 21,3 \\
\hline 2000 TL ve altı & 64 & 38,0 \\
2001- 3000 TL & 114 & 32,0 \\
3001- 5000 TL & 96 & 8,7 \\
5001 TL ve üstü & 26 & 100,0 \\
Toplam & 300 & \\
\hline
\end{tabular}

Ankete katılan bireylerin cinsiyetlerine göre frekans dağılımları Tablo 1'de verilmiştir. Elde edilen bulgulara göre kadın katılımcıların oranı $\% 45.3$ ve erkek hastalarınoranı \%54.7 olarak gerçekleşmiştir.. Elde edilen bulgulara göre en büyük yığılma \%57.3 ile 41 yaş ve üstü grubunda ve en az yığılma da \%7.0 ile 31-35 yaş grubunda olduğu gözlemlenmiştir. Elde edilen bulgulara göre; katılımcıların \%77.0'ının Lise, \%13.7'sinin Ön Lisans, \%9.0'ının Lisans ve \%0.3'ünün Doktora eğitimine sahip oldukları gözlemlenmiştir.
Tablo 2. Ankete katılan bireylerin "Hasta haklart ile ilgili bilginiz var mı?" sorusuna verdikleri cevapların frekans dağılımı

\begin{tabular}{lcc}
\hline Soru07 & Kişi & $\%$ \\
\hline Evet & 53 & 17.7 \\
Hayır & 139 & 46.3 \\
Kismen & 108 & 36.0 \\
Total & 300 & 100.0 \\
\hline \multicolumn{2}{c}{ Ankete katılan bireylerin "Hasta hakları ile ilgili }
\end{tabular}

bilginiz var mi?" sorusuna verdikleri cevapların frekans dağılımı Tablo 2'de verilmiştir. Elde edilen bulgulara göre katılımcıların \%17.7'sinin Evet, \%46.3'ünün Hayır ve \%36.0’ının Kısmen cevabını verdiği gözlemlenmiştir.

Tablo 3. Ankete katılan bireylerin "Hasta haklarl yönetmeliğini okudunuz mu? ” sorusuna verdikleri cevapların frekans dă̆ılımı

\begin{tabular}{lcc}
\hline hasthak22 & Kişi & $\%$ \\
\hline Evet & 63 & 21.0 \\
Hayır & 154 & 51.3 \\
Okumadım ama bilgim var & 83 & 27.7 \\
Total & 300 & 100.0 \\
\hline
\end{tabular}

Ankete katılan bireylerin "Hasta hakları yönetmeliğini okudunuz mu?" sorusuna verdikleri cevapların frekans dağılımı Tablo 3'de verilmiştir. Elde edilen bulgulara göre katılımcıların \%21.0'1nın "Evet”, \%51.3'ünün “Hayır" ve \%27.7'sinin "Okumadım ama bilgim var" cevaplarını verdikleri gözlemlenmiştir.

Tablo 4. Hasta memnuniyeti ölçeği, idari hizmetler boyutu maddeleri için frekans ve açıklayıcı istatistik değerleri

\begin{tabular}{lcccccccccccc}
\hline & Çok kötü & \multicolumn{3}{c}{ Kötü } & \multicolumn{3}{c}{ Kararsııı } & İyi & \multicolumn{3}{c}{ Cok iyi } \\
\hline & Sayı & Yüzde & Say1 & Yüzde & Sayı & Yüzde & Sayı & Yüzde & Sayı & Yüzde & Ort. & Std. S. \\
hastmem01 & 4 & 1.3 & 14 & 4.7 & 16 & 5.3 & 198 & 66.0 & 68 & 22.7 & 4.04 & 0.766 \\
hastmem07 & 17 & 5.7 & 106 & 35.3 & 105 & 35.0 & 65 & 21.7 & 7 & 2.3 & 2.80 & 0.923 \\
hastmem09 & 20 & 6.7 & 126 & 42.0 & 98 & 32.7 & 51 & 17.0 & 5 & 1.7 & 2.65 & 0.896 \\
hastmem12 & 2 & .7 & 0 & .0 & 41 & 13.7 & 216 & 72.0 & 41 & 13.7 & 3.98 & 0.578 \\
& & & & & & & & & ort_idari_m & 3.37 & 0.473 \\
\hline
\end{tabular}

Hasta memnuniyeti ölçeği, idari hizmetler boyutu maddeleri için frekans ve açıklayıcı istatistikler Tablo 4'de verilmiştir. Yüzdelik dağılımları incelendiğinde "hastmem01" ve "hasthak14" maddeleri için cevapların "İyi" seçeneğinde yoğunlaştı̆̆1 ve "hastmem07" ve "hastmem09" maddeleri için

Tablo 5. Hasta memnuniyeti ölçeği, ilgi ve nezaket boyutu maddeleri için frekans ve açıklayıcı istatistik değerleri ise cevapların "kötü" ve "Kararsızım" maddelerinde yoğunlaştığı görülmektedir. Ortalamalar incelendiğinde en düşük ortalamanın "hasthak09" maddesinde ve en yüksek ortalamanın "hastmem01" maddesinde olduğu görülmektedir.

\begin{tabular}{|c|c|c|c|c|c|c|c|c|c|c|c|c|}
\hline & Çok kötü & & Kötü & & Kara & Izım & İyi & & Çok iy & & & \\
\hline & Sayı & Yüzde & Sayı & Yüzde & Sayı & Yüzde & Say1 & Yüzde & Say1 & Yüzde & Ort. & Std. S. \\
\hline hastmem03 & 1 & .3 & 0 & .0 & 7 & 2.3 & 151 & 50.3 & 141 & 47.0 & 4.44 & 0.578 \\
\hline hastmem05 & 2 & .7 & 7 & 2.3 & 52 & 17.3 & 154 & 51.3 & 85 & 28.3 & 4.04 & 0.781 \\
\hline hastmem11 & 2 & .7 & 15 & 5.0 & 21 & 7.0 & 206 & 68.7 & 56 & 18.7 & 4.00 & 0.720 \\
\hline \multicolumn{11}{|c|}{ ort_neza_m } & 4.22 & 0.513 \\
\hline
\end{tabular}

Hasta memnuniyeti ölçeği, ilgi ve nezaket boyutu maddeleri için frekans ve açıklayıcı istatistikler Tablo 5'de verilmiştir.

e-ISSN:2148-2683 
görülmektedir. Ortalamalar incelendiğinde en düşük ortalamanın "hasthak11" maddesinde ve en yüksek ortalamanın

"hastmem03" maddesinde olduğu görülmektedir.

Tablo 6. Hasta hakları ile Genel memnuniyet ve alt boyutlarının Servis değişkeni bakımından incelenmesi

\begin{tabular}{|c|c|c|c|c|c|c|c|}
\hline & Servis & $\mathbf{N}$ & Ort. & Std. Sapma & $\mathbf{F}$ & & Farklııı̆ın kaynağı \\
\hline \multirow{4}{*}{ Hasta hakları algısı } & Genel cerrahi & 96 & 2.82 & 0.671 & 1.255 & 0.287 & \\
\hline & KBB & 159 & 2.93 & 0.608 & & & \\
\hline & Genel cerrahi servisi & 38 & 2.80 & 0.441 & & & \\
\hline & Total & 293 & 2.87 & 0.611 & & & \\
\hline & & & & & & & Çizelge 38 Devam \\
\hline \multirow{4}{*}{ İdari hizmetler } & Genel cerrahi & 96 & 3.27 & 0.445 & 5.978 & 0.003 & KBB ile Genel cerrahi \\
\hline & KBB & 159 & 3.45 & 0.482 & & & KBB ile Genel cerrahi servisi \\
\hline & Genel cerrahi servisi & 38 & 3.24 & 0.461 & & & \\
\hline & Total & 293 & 3.36 & 0.476 & & & \\
\hline \multirow{4}{*}{ İlgi ve nezaket } & Genel cerrahi & 96 & 4.20 & 0.592 & 2.376 & 0.095 & \\
\hline & KBB & 159 & 4.27 & 0.460 & & & \\
\hline & Genel cerrahi servisi & 38 & 4.08 & 0.502 & & & \\
\hline & Total & 293 & 4.22 & 0.514 & & & \\
\hline \multirow[t]{4}{*}{ Tibbi hizmetler } & Genel cerrahi & 96 & 3.58 & 0.587 & 2.122 & 0.122 & \\
\hline & KBB & 159 & 3.72 & 0.535 & & & \\
\hline & Genel cerrahi servisi & 38 & 3.61 & 0.648 & & & \\
\hline & Total & 293 & 3.66 & 0.570 & & & \\
\hline \multirow[t]{4}{*}{ Genel memnuniyet } & Genel cerrahi & 96 & 3.76 & 0.450 & 4.513 & 0.012 & KBB ile Genel cerrahi \\
\hline & KBB & 159 & 3.88 & 0.355 & & & KBB ile Genel cerrahi servisi \\
\hline & Genel cerrahi servisi & 38 & 3.71 & 0.417 & & & \\
\hline & Total & 293 & 3.82 & 0.401 & & & \\
\hline \multicolumn{4}{|c|}{$\begin{array}{l}\text { Hasta hakları ile Genel memnuniyet ve alt boyutlarının } \\
\text { Servis değişkeni bakımından farklılık olup olmadığ ANOVA } \\
\text { testi ile incelenerek elde edilen bulgular Tablo 6'da verilmiştir. } \\
\text { Elde edilen bulgulara göre İdari hizmetler ve Genel Memnuniyet } \\
\text { ölçeklerinde Servis değişkeni bakımından istatistiksel olarak } \\
\text { anlamlı fark bulunmuşur. Farklılı̆ı̆ kaynağı olan gruplar } \\
\text { TUKEY testiyle belirlenerek ilgili boyutların karşsında } \\
\text { yazılmıştır. }\end{array}$} & \multicolumn{4}{|c|}{$\begin{array}{l}\text { Çalışmada hasta hakları algısı (ortalama: } 2,87 \text { ) olarak } \\
\text { hesaplanmıştır. Bu sonuç hastaların hasta hakları uygulamas } \\
\text { algısının düşük olduğu diğer bir ifadeyle hastane çalışanlarının } \\
\text { (doktor, yönetici ve diğer ilgili personel) hasta hakları } \\
\text { konusunda titiz davranmadikları düşünülebilir. Buna karşın } \\
\text { hastaların memnuniyetlerinin daha yüksek olduğu (idari } \\
\text { hizmetlerden memnuniyet: } 3,37 \text {, ilgi ve nezaketten memnuniyet: } \\
4,22 \text {, tıbbi hizmetlerden memnuniyet: 3,66 ve genel } \\
\text { memnuniyet: } 3,82 \text { gözlemlenmiştir. }\end{array}$} \\
\hline
\end{tabular}

\section{Sonuç}

$\mathrm{Bu}$ çalışma hastane işletmesinde tedavi gören hasta ve yakınlarının görüşlerine göre hasta hakları uygulamalarının hasta memnuniyetine olan etkisinin incelenmesi amaciyla gerçekleştirilmiştir.

Hasta memnuniyetinin üzerinde en büyük etkiye sahip değiş̧kenlerden birisi kuşkusuz hasta hakları uygulamasıdır. Bu çalışmada da bu gerçekten yola çıkarak hastaların hem hasta hakları konusundaki bilgileri, hem tedavi gördükleri kurumlardaki hasta hakları uygulama algılarını hem de gördükleri sağlık hizmetinden memnuniyet algıları araştırılmıştır.

Hasta hakları ve hasta memnuniyeti ölçeklerinin her ikisi için de güvenirlik analizi için Cronbach's Alpha katsayısı hesaplanmış, yapısal geçerliliği için doğrulayıcı faktör analizi (DFA) uygulanmıştır. Anket soruları içinde hasta hakları algısını ölçmek amacıyla anket formunun Hasta Hakları bölümünde 11., 14., 15., 16., 17., 18., 19., 20. ve 21. sorular sorulmuştur. Hasta memnuniyeti algısı ise ayrı bir ölçek olarak 14 sorudan oluşan bir bölümde sorulmuştur. Araştırmanın evrenini belirlenen 1 yıl içinde uygulama yapılması için seçilen poliklinik hastaları ve serviste yatan hastalar oluşturmaktadır. Hastane yöneticilerinden alınan sözlü bilgiye göre hastaneye araştırmaya konu olan yılda 50000 hasta gelmiştir. Çalışmanın çerçevesi ve kısıtlarına göre örneklem çapı $\% 95$ güvenirlik $\% 6$ duyarlılık düzeyinde olması uygun görülmüştür. Buna göre örnek çap 275 olarak tespit edilmiştir.

Araştırma problemi ile ilgili olarak çalışmanın temel problemi olan hasta hakları algısının hasta memnuniyeti üzerine etkisi istatistiksel olarak anlamlı bulunmuştur. Ancak hasta memnuniyetinin alt boyutlarına inildiğinde ilginç bir durumla karşılaşılmıştır: Hasta hakları uygulaması algısı genel memnuniyet, tıbbi hizmetler ve ilgi-nezaket algıları üzerinde etkili olurken idari hizmetlerden memnuniyet algisı üzerindeki etkisi istatistiksel olarak anlamlı bulunamamıştır.

\section{8. Öneriler}

Sağlık sisteminin, insan sağlığına yönelik hizmet sunması, sağlık personelinin katılımını önemli kılmaktadır. Hizmet kalite standartları sağlanırken, hastalarla olan iletişimin artırılması için, hasta sağlık personeli iliş̧isine ait eğitimlerin artırılması sağlanmalıdır. Hastalara özgü, sağlık hizmetlerinden nasıl faydalanacağına yönelik, eğitim seminerlerinin artırılması sağlanmalıdır. Hastane kurallarını içeren broşür ve kitapçıkların hastaların odalarına ve boş zamanlarını geçirdikleri alanlara bırakılması, afişlerin hastane giriş ve servis panolarına asılması ve hastanenin merkezi ses sisteminden hastaların rahatsız olmayacağı saatlerde periyodik aralıklar ile duyurulması sağlanmalıdır. Sağlık personelinin eğitim müfredatında, hasta haklarının ayrı bir ders olarak verilmesi sağlanmalıdır. Hasta hakları ile ilgili hizmet içi eğitim programlarına, sağlık personelinin katılması zorunlu hale getirilmelidir. T.C. Sağlık Bakanlığı, "sağlıkta dönüşüm reformu" dâhilinde, sağlık personeline, hasta hakları ile ilgili sertifikalı eğitim programları zorunlu hale getirilmelidir. T.C. Sağlık Bakanlığı, döner sermaye 
yönetmeliğinde, performans puanlanmasına, hastanın, hastalığı, yapılan tedavi ve uygulamalar hakkında bilgilendirilmesi de dâhil edilmelidir.

$\mathrm{Bu}$ konuda yapılan çalışmalar oldukça azdır. $\mathrm{Bu}$ çalışma, hasta hakları uygulamalarının hasta memnuniyetine etkisinin incelenmesi amaciyla kamu hastanesi üzerine yapılan bir araştırmadır ve bu amaçla x ilçesinin x kamu hastanesinde yapılmıştır. Bu nedenle araştırmanın sonuçları Türkiyede'ki tüm kamu hastanelere genellenemez. Araştırmanın tüm il veya ilçeleri kapsayacak şekilde, genellenebilir bir sonuca ulaşması için farklı kamu hasta hakları uygulamalarına ilişkin doktor, hemşire ve hastane personeli gibi sağlık çalışanları araştırmaya dahil edilerek araştırmanın yapılması ve daha geniş topluluğa uygulanarak geliştirilebileceği önerilebilir.

Elde edilen sonuca göre hastaların hasta hakları uygulaması algısındaki iyileşme (sağlık kurumlarının ve çalışanlarının bu konuda titiz davranmaları) hastaların genel memnuniyeti, tıbbi hizmetlerden memnuniyeti ve ilgi-nezaket hizmetlerinden memnuniyetlerini artırmaktadır. Ancak aynı etki idari hizmetlerden memnuniyet için geçerli olmamaktadır. Bu sonuç hem sağlık sektörü için hem de bu alanda bilimsel çalışmalar yayan bilim çevresi için dikkatle incelenmesi gereken bir sonuçtur.

$\mathrm{Bu}$ çalışmada hasta hakları uygulamasının hasta memnuniyetine etkisi regresyon analizi yöntemiyle incelenmiştir. Benzer çalışmalar etki analizi için yapısal eşitlik modeli gibi farklı yöntemler kullanılarak yapılması araştırma probleminin daha iyi anlaşılmasını sağlayacaktır. Ayrıca hasta memnuniyetini etkileyen farklı faktörlerin de modele dâhil edilmesi hasta memnuniyetinin daha iyi anlaşılmasını sağlayacaktır. Bu çalışma daha geniş imkânlarla birden fazla sağlık kurumunda geniş çaplı bir çalışma ile geliştirilebilir ve iyileştirebilir.

\section{Kaynakça}

Kavuncubaşı, Ş. Ve Yıldırım, S. (2010). Hastane Ve Sağlık Kurumları Yönetimi, Ankara, Siyasal Kitabevi.

Dağıtım.

Aksoy, O. (2001). 'Sağlık Hakları Ve Hasta Hakları", Yeni Türkiye Dergisi, 40: 12.

Özer, A. Ve Çakı1, E. (2007). "Sağlık Hizmetlerinde Hasta Memnuniyetini Etkileyen Etmenler", Tıp Araştırmaları Dergisi, Malatya, 5(3): 141.

Özlü, T. (2007). 'Hekimler Ve Hasta Hakları', Sağlık Hakkı Dergisi, Trabzon, 2: 46.

Petrescu, I.A. Ve Simmons, R. (2008). 'Human Resource Management Practicesandworkers' Jobsatisfaction', International Journal Of Manpower, 29(7), 653.

Erdem,R. (2008). 'Hasta Memnuniyetinin Hasta Bağlılığ Üzerine Etkisi”, Erciyes Üniversitesi İktisadi ve İdari Bilimler Fakültesi Dergisi, Erciyes, 31: 95-110

Öz, S. (2007). 'İnsan Hakları Düzenlemelerinin Türk Kamu Yönetimine Etkisi", Yüksek Lisans Tezi, Süleyman Demirel Üniversitesi Sosyal Bilimler Enstitüsü, Isparta.

Hatun, Ş. (1999). Hasta Hakları,İstanbul, İletişism Yayınları.

Çiçin, F. (2018) "Kanserli Hastalara Sunulan Sağlık Hizmetlerinde Hasta Memnuniyeti ve Trakya Üniversitesi Balkan Onkoloji Hastanesi Örneği”, Trakya Üniversitesi, SBE, YLT, s.34.
Akkaya, G.Mehtap, E. B. ve Akkaya, C. (2012). '’Acil Servise Başvuran Hastaların Memnuniyetini Etkileyen Faktörler", Türkiye Acil Tıp Dergisi, Bursa, 12(2): 63.

Eren, E. (2006). Örgütsel Davranış ve Yönetim Psikolojisi,İstanbul, Beta Yayın.

Mangan, S. (2006). Kartal Eğitim ve Araştırma Hastanesi 'nde hasta hakları uygulamalarının sosyolojik açıdan incelenmesi. İstanbul: Mimar Sinan Güzel Sanatlar Üniversitesi, Sosyal Bilimler Enstitüsü, Sosyoloji Anabilim Dalı, Yüksek Lisans Tezi.

T.C. Sağlık Bakanlığı, (Erişim),

Https://Www.Saglik.Gov.Tr/Tr,10461/Hasta-HaklariYonetmeligi.Html, 05.03.2019

T.C. Sağlık Bakanlığı, Sağlık Hizmetlerinin Sosyalleştirilmesi Hakkında Kanun, Madde 2, Rg: 1961, Sayı: 224, (Erişim),

Http://Www.Mevzuat.Gov.Tr/Mevzuatmetin/1.4.224.Pdf, 14.03.2019

Türkiye Büyük Millet Meclisi [Tbmm], (Erişim),

Https://Www.Tbmm.Gov.Tr/Komisyon/İnsanhaklari/Pdf01/203208.Pdf

Dünya Sağlık Örgütü [Who], (2005). Constitution Of The World Healthorganization. In: Basic Documents, World Healthorganization, Geneva. 